\title{
Pyricularia grisea causando manchas foliares na cultivar BRS capileto de capim-elefante (Pennisetum purpureum Schumach.) X milheto (Pennisetum glaucum (L.) R. Br.)
}

\author{
Jaqueline Rosemeire Verzignassi ${ }^{1}$; Celso Dornelas Fernandes ${ }^{1}$; Francisco José da Silva Lédo²; Margareth Vieira \\ Batista $^{1}$; Carolina de Arruda Queiroz ${ }^{1}$; Hugo Soares Corado ${ }^{1}$; Luiz Sebastião Poltronieri ${ }^{3}$; Lenise Castilho Monteiro ${ }^{1}$; \\ Janaína Iara Silva ${ }^{1}$; Gleiciane de Lima Benteo ${ }^{1}$; Juarez Campolina Machado ${ }^{2}$
}

${ }^{1}$ Embrapa Gado de Corte, Avenida Rádio Maia, 830, CEP 79106-550, Campo Grande, MS. ${ }^{2}$ Embrapa Gado de Leite, Rua Eugênio do Nascimento, 610, CEP 36038-330, Juiz de Fora, MG. ${ }^{3}$ Embrapa Amazônia Oriental, Tv. Enéas Pinheiro, S/N, CEP 66095-100, Belém, PA.

Autor para correspondência: Jaqueline Rosemeire Verzignassi (jaqueline.verzignassi@embrapa.br)

Data de chegada: 01/10/2012. Aceito para publicação em: 30/03/2013.

O capim-elefante (Pennisetum purpureum Schumach.) é, reconhecidamente, uma das gramíneas forrageiras de mais alto potencial produtivo, adaptando-se muito bem às condições de clima e solo de praticamente todo o Brasil. Contudo, uma das principais dificuldades existentes para a expansão do cultivo do capim-elefante está relacionada à sua forma de propagação, realizada por meio de estacas, o que aumenta o custo de transporte e plantio da forrageira, impossibilita o armazenamento do material propagativo por longo período, além de dificultar a distribuição das cultivares melhoradas. Os híbridos interespecíficos hexaplóides, obtidos pela combinação genética entre o milheto (Pennisetum glaucum (L.) R. Br.) e o capimelefante, têm-se revelado como uma boa alternativa para a obtenção de cultivares superiores que se propagam por meio de sementes. Além de melhor qualidade forrageira, os híbridos hexaplóides apresentam elevada produção de sementes grandes e viáveis. Neste contexto, a Embrapa Gado de Leite, em parceria com a Unipasto (Associação para o Fomento à Pesquisa de Melhoramento de Forrageiras) desenvolveu, recentemente, a população hexaplóide de Pennisetum purpureum x Pennisetum glaucum, denominada cultivar BRS Capileto, registrada no RNC sob o número 28752 e cujo lançamento está previsto para o ano de 2014. Em campos de multiplicação de sementes de BRS Capileto na Embrapa Gado de Corte, Campo Grande, MS, foram observadas, em folhas das plantas adultas e com idade aproximada de sete meses, pontuações castanhoavermelhadas, que evoluíam para manchas elípticas de até $2 \mathrm{~cm}$ de comprimento por $0,5 \mathrm{~cm}$ de largura (Figura 1A). As lesões individuais coalesciam, formando extensas áreas necrosadas, com queima total das folhas. Da interface das lesões e tecido sadio foram retiradas porções para isolamento do patógeno em ágarágua. Os isolados do fungo obtidos foram transferidos para BDA e as colônias formadas apresentaram aspecto cinza escuro e cotonoso (Figura 1B). Os conídios, de formato piriforme, hialinos, na maioria com três células e dois septos, apresentavam dimensões de 12,50-24,98-30,00 x 5,00-9,25-12,50 $\mu \mathrm{m} \mathrm{e}$ apêndice basal no ponto de ligação com o conidióforo (Figura 1C). Observaram-se, ainda, que os conídios germinavam a partir da célula apical (Figura 1D). Os conidióforos encontrados apresentavam coloração hialina e formato reto a curvo (Figura $1 \mathrm{C}$ e 1D). O fungo foi identificado como Pyricularia grisea (Cooke) Sacc. e ocorre em mais de 50 gramíneas, entre elas o arroz (Oryza sativa) e o trigo (Triticum aestivum). O referido
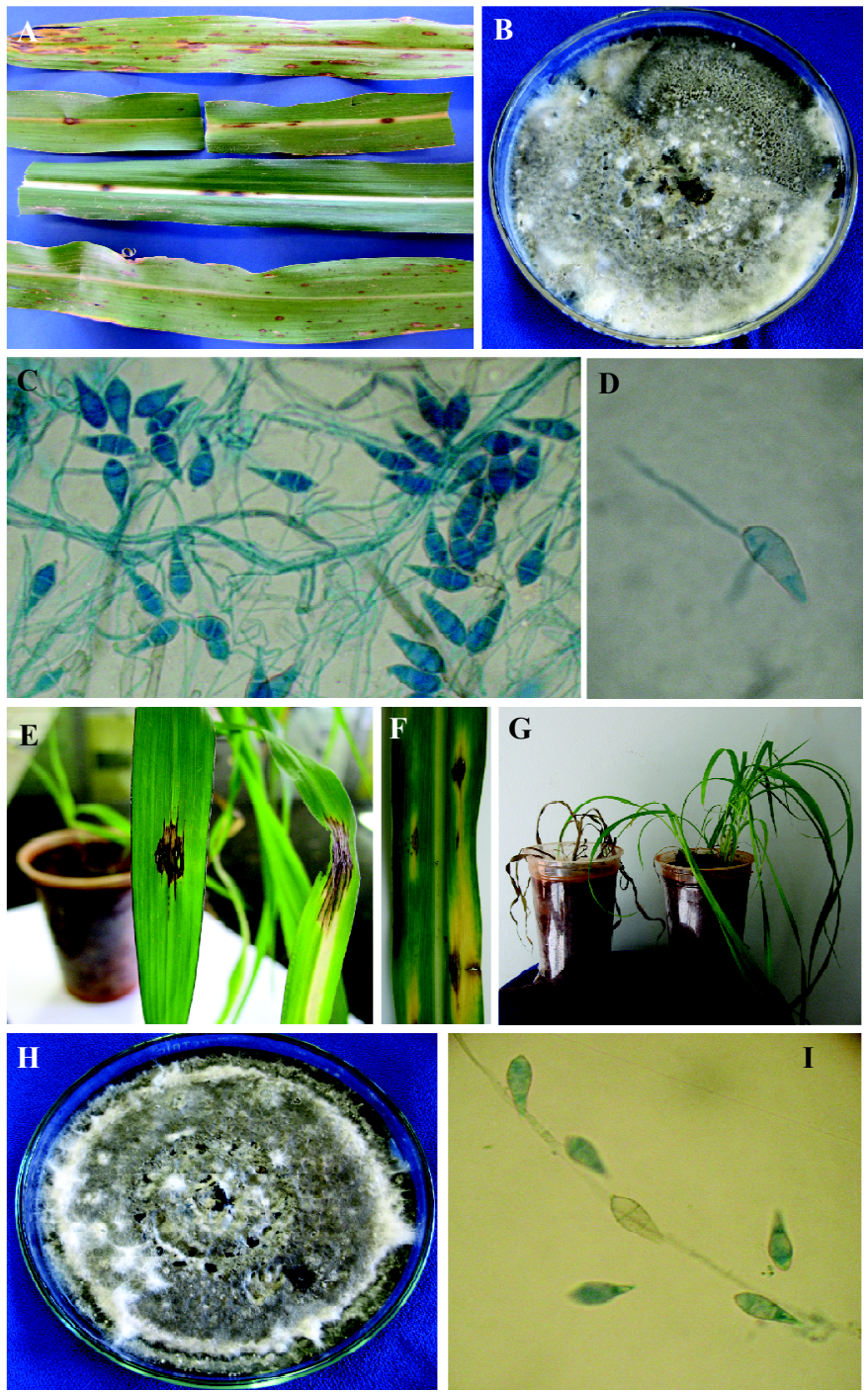

Figura 1. Manchas foliares em capim-elefante-híbrido BRS Capileto causada por Pyricularia grisea: sintomas da doença (A); colônia do fungo isolado (B); conídios e conidióforos do fungo (C e D); sintomas em plantas inoculadas (E); sintomas em folhas destacadas inoculadas (F); sintomas avançados em plantas inoculadas e planta testemunha $(\mathrm{G})$; colônia e estruturas do patógeno reisolado ( $\mathrm{H} \mathrm{e} \mathrm{I}$ ). 
isolado foi inoculado em plantas sadias de 40 dias de idade e em folhas sadias destacadas provenientes de plantas adultas do campo. Em ambos os casos, discos de cultura do fungo foram colocados sobre as folhas previamente feridas e o material inoculado foi mantido em câmara úmida $\left(90 \% \mathrm{UR} ; 30^{\circ} \mathrm{C}\right)$ por dois dias. Após, as folhas destacadas inoculadas foram mantidas em temperatura ambiente de laboratório e as plantas inoculadas foram mantidas em casa-de-vegetação. Sintomas idênticos aos encontrados no campo foram reproduzidos aos oito dias da inoculação (Figuras 1E e 1F). Além disso, uma suspensão de micélio do fungo foi preparada e aspergida sobre plantas de 40 dias de idade e, após dois dias sob câmara úmida $\left(90 \% \mathrm{UR} ; 30^{\circ} \mathrm{C}\right)$ e quinze dias em condições de laboratório, apresentaram todas as suas folhas secas (Figura $1 \mathrm{G}$ ). Do material com sintomas decorrentes da inoculação procedeu-se o reisolamento do patógeno (Figuras $1 \mathrm{H}$ e 1I). Partes das plantas coletadas com sintomas e utilizadas para as análises foram herborizadas e armazenadas no Herbário da Universidade Federal de Mato Grosso do Sul sob o número de registro CGMS-35.093. Este é o primeiro relato da ocorrência de Pyricularia grisea em Pennisetum purpureum X Pennisetum glaucum BRS Capileto. 